\title{
Samuel McDonald McCann, MD Pioneer in Neuroimmunomodulation
}

\author{
September 8, 1925 to March 16, 2007
}

'Don' McCann died on March 16, 2007 in Buenos Aires after an intense battle with cancer. He approached the latter part of his life with the same kind of vigor he showed earlier, writing research papers and giving lectures around the world until a few weeks before his death. He was always a leader in, and a strong spokesman for, the field and his international scientific reputation, made first in neuroendocrinology, added luster to the burgeoning field of neuroimmunomodulation research. He received many awards, including the $\mathrm{H}$. Novera Spector Award for excellence in the field in 2005 at the 6th Congress of the International Society for Neuroimmunomodulation meeting in Athens.

Professor McCann was a staunch Texan both in mentality and demeanor. Conservative philosophically and never short of an opinion on any topic, Don was the definition of bonhomme, always in good humor and glad to meet anyone. Perhaps above all, his exceptional energy level and enthusiasm for science and his great curiosity marked most of his days. His memory of scientific details, years after the studies were put to rest, amazed his colleagues. These positive features attracted students of many nationalities to his laboratories and the majority of those students lived by his example and became leaders in research.

His interest and capabilities in the field of neuroimmunomodulation can be seen to arise from a background in physiological systems developed during his years as a student at Rice University and during his medical training at the University of Pennsylvania, the latter a hotbed

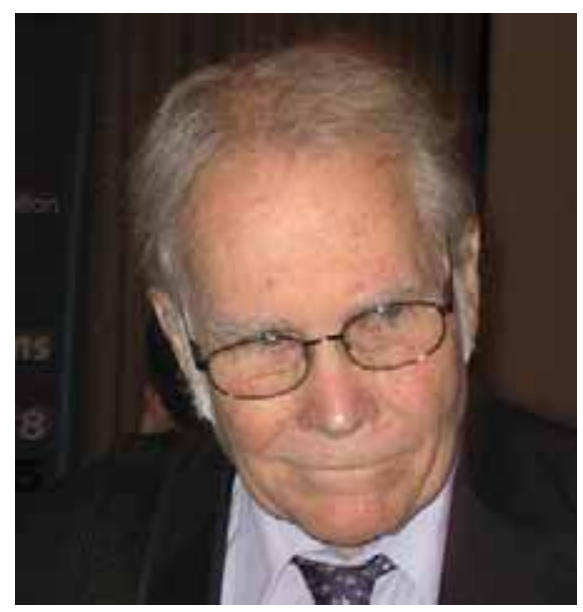

of systems physiology research at the time. Don's innate powers were recognized early and he was accepted for further medical training at Harvard Medical School/ Massachusetts General Hospital where he was able to integrate clinical observations with underlying physiological processes he studied in the basic science laboratory. For many years, Professor McCann served as Chairman of Physiology at The University of Texas Southwestern Medical Center at Dallas. During his tenure he developed the department into a first tier organization, recognized around the world. It was within this department that McCann co-founded the NeuroImmunoModulation journal.

\begin{tabular}{ll}
\hline KARGER & @ 2007 S. Karger AG, Basel \\
1021-7401/07/0141-0002\$23.50/0 \\
$\begin{array}{l}\text { Eax +41 61 } 3061234 \\
\begin{array}{l}\text { E-Mail karger@karger.ch } \\
\text { www.karger.com }\end{array}\end{array}$ & $\begin{array}{l}\text { Accessible online at: } \\
\text { www.karger.com/nim }\end{array}$
\end{tabular}


Don's accomplishments are many and certainly most are known by the readers of NeuroImmunoModulation. Suffice it to say that his seminal contributions to science were recognized by all and they earned him recognition and acceptance by both The National Academy of Sciences and the American Academy of Arts and Sciences.

McCann leaves an amazing legacy of persons who admired him and his abilities. We will all miss interacting with him in games of hypotheses about how the nervous system, immune processes, and all body organs and systems interact to support and protect life.

Don was born in Houston, Tex. on September 8, 1925. He is survived by his wife, Valeria Rettori, MD, of Buenos Aires, Argentina, daughters Maggie White of El Dorado Hills, Calif. and Karen Slaughter of Dallas, Tex. and a son, Samuel Donald McCann of Huntsville, Tex.

James Lipton, Los Angeles, Calif. 